Supplement of

\title{
Uptake of nitric acid, ammonia, and organics in orographic clouds: mass spectrometric analyses of droplet residual and interstitial aerosol particles
}

Johannes Schneider et al.

Correspondence to: Johannes Schneider (johannes.schneider@mpic.de)

The copyright of individual parts of the supplement might differ from the CC-BY 3.0 licence. 
Table S1: Relative ionization efficiencies (RIE) used in this work. RIE $_{\mathrm{NH} 4}$ and $\mathrm{RIE}_{\mathrm{SO} 4}$ were inferred from calibrations during this field study. $\mathrm{RIE}_{\mathrm{NO} 3}, \mathrm{RIE}_{\mathrm{org}}$, and $\mathrm{RIE}_{\mathrm{Cl}}$ are default values from published laboratory measurements or field intercomparisons (Alfarra et al., 2004; Takegawa et al., 2005; Canagaratna et al., 2007).

\begin{tabular}{lccccc}
\hline Instrument & $\mathrm{RIE}_{\mathrm{NO} 3}$ & $\mathrm{RIE}_{\mathrm{NH} 4}$ & $\mathrm{RIE}_{\mathrm{SO} 4}$ & $\mathrm{RIE}_{\mathrm{Org}}$ & $\mathrm{RIE}_{\mathrm{Cl}}$ \\
\hline C-ToF-AMS & 1.1 & 4.11 & 0.70 & 1.4 & 1.3 \\
HR-ToF-AMS & 1.1 & 3.74 & 1.49 & 1.4 & 1.3 \\
\hline
\end{tabular}



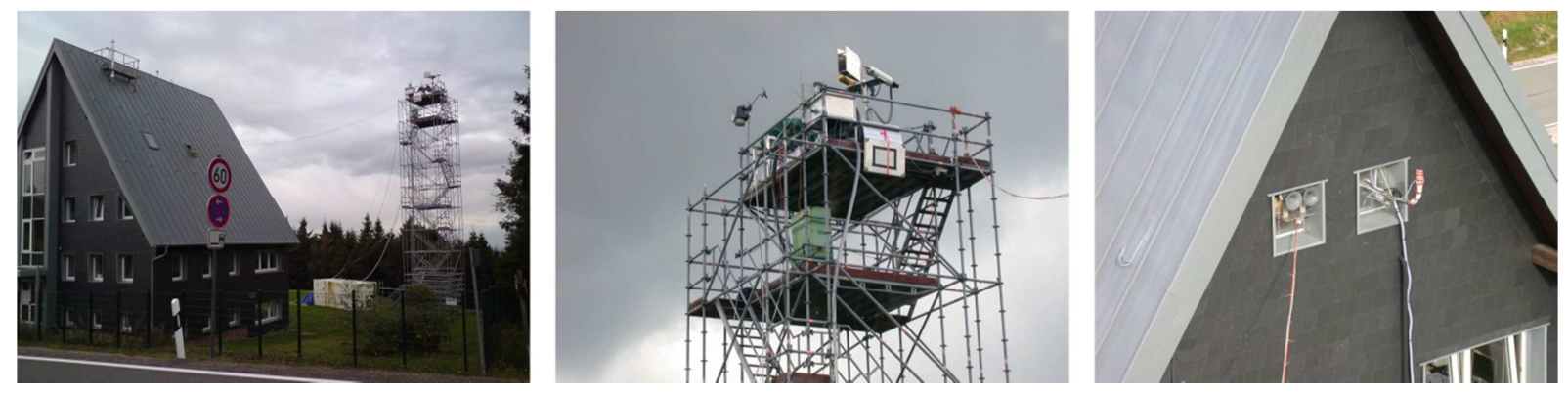

Figure S1: Photographs of the summit site. Left: Measurement building and tower; middle: instruments on the $20 \mathrm{~m}$ tower; right: CVI and interstitial inlet at ca. $15 \mathrm{~m}$ altitude, facing south-west $\left(215^{\circ}\right)$. 
a) $\begin{array}{lllll}17.09 .2010 & 24.09 .2010 & 01.10 .2010 & 08.10 .2010 \quad 15.10 .2010 \quad 22.10 .2010\end{array}$
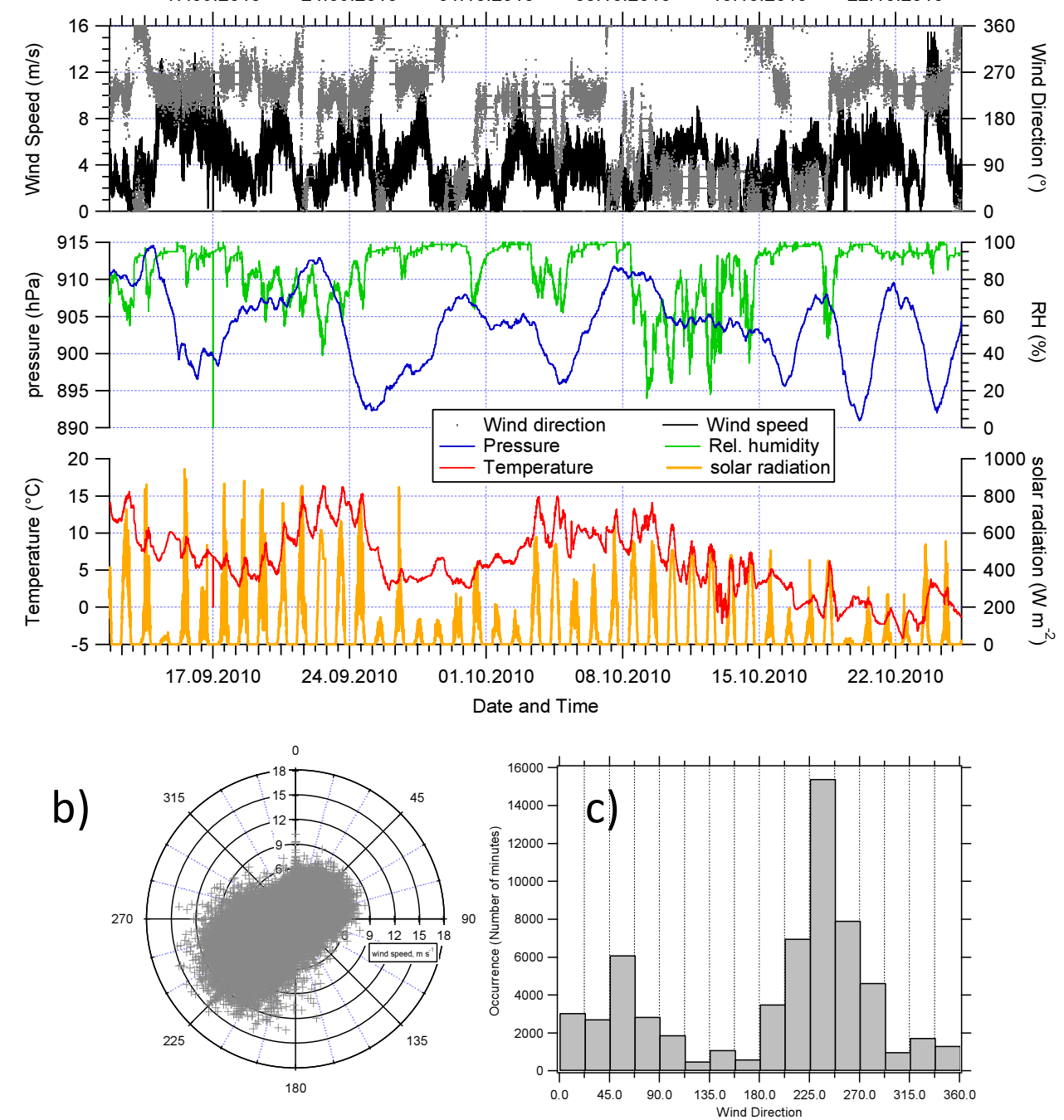

Figure S2. Overview of the meteorological parameters measured by the Vantage Pro weather station on the tower at the summit site. a) time series of relevant parameters; b) polar graph with wind speeds and wind directions; c) histogram of wind directions. 


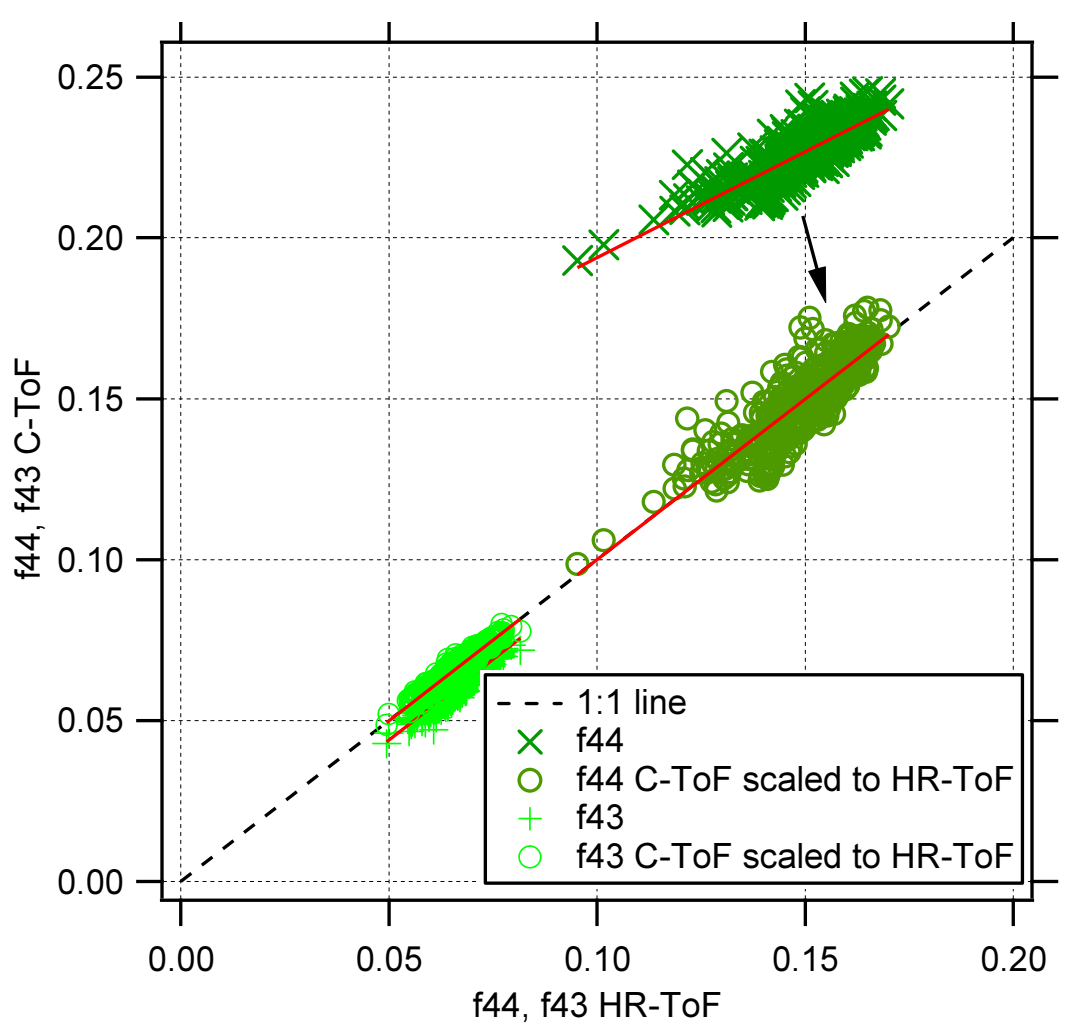

Figure S3. Scaling of $f_{44}$ (dark green) from C-ToF-AMS to HR-ToF-AMS. For $f_{43}$ (light green), the scaling was only marginal. This scaling is based on the cloud-free intercomparison period from September 19 to 25 . The red lines are linear fits to the data.

Original values:

$f_{44, \mathrm{C}-\mathrm{ToF}}$ Vs $f_{44, \mathrm{HR}-\mathrm{ToF}}:$ slope $=0.660$, offset $=0.128, \mathrm{r}^{2}=0.75$

$f_{43, \mathrm{C}-\mathrm{ToF}}$ Vs $f_{43, \mathrm{HR}-\mathrm{ToF}}:$ slope $=1.003$, offset $=-0.006, \mathrm{r}^{2}=0.91$.

10 Scaling equations:

$f_{44, \mathrm{C}-\mathrm{ToF}, \mathrm{corr}}=\left(f_{44, \mathrm{C}-\mathrm{ToF}, \text { measured }}-0.128\right) \times 1.514$

$f_{43, \mathrm{C}-\mathrm{ToF}, \text { corr }}=\left(f_{43, \mathrm{C}-\mathrm{ToF}, \text { measured }}+0.006\right) \times 0.997$ 

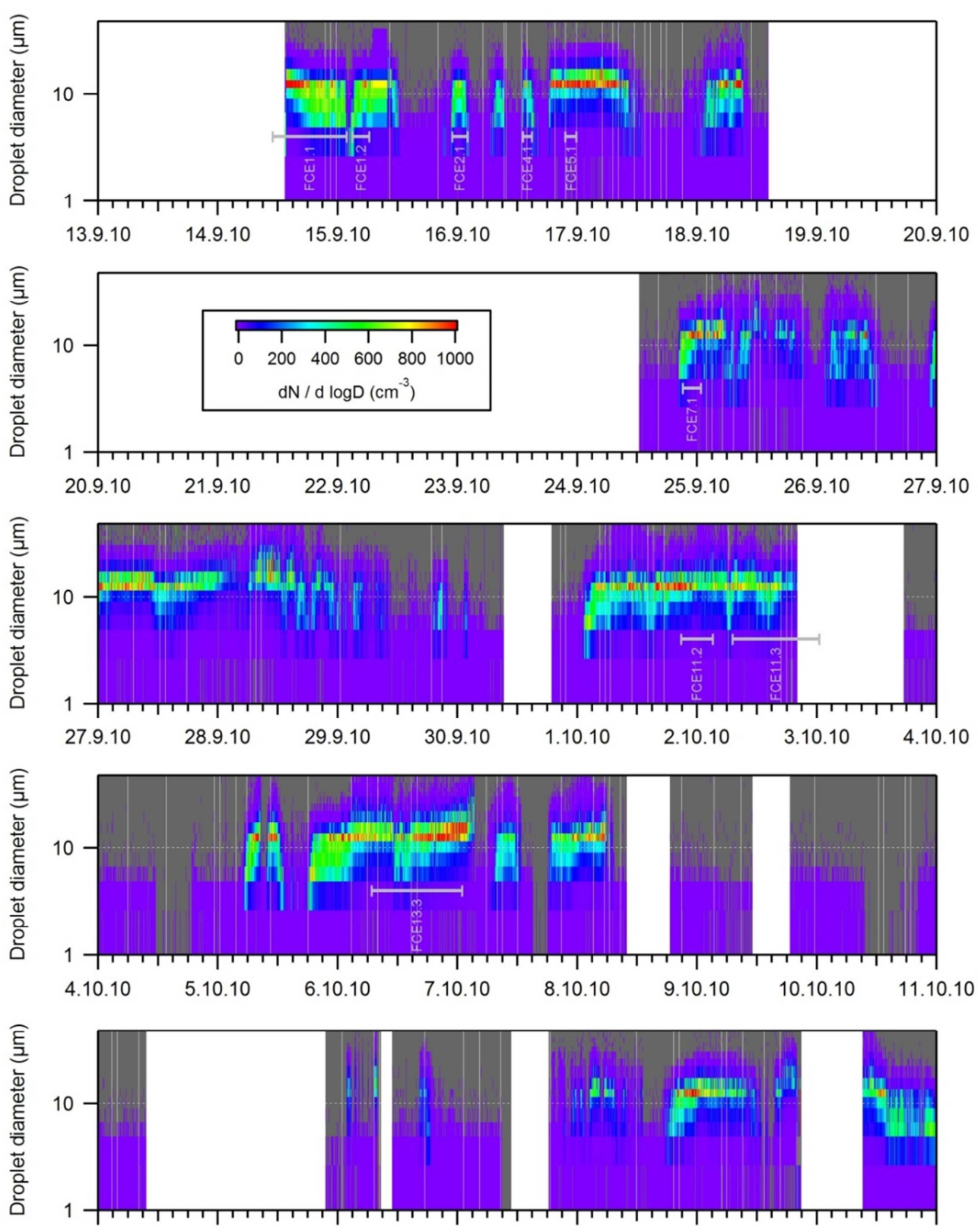
$\begin{array}{lll}11.10 .10 & 12.10 .10 & 13.10 .10\end{array}$
14.10.10
15.10.10
16.10.10
17.10.10
18.10.10

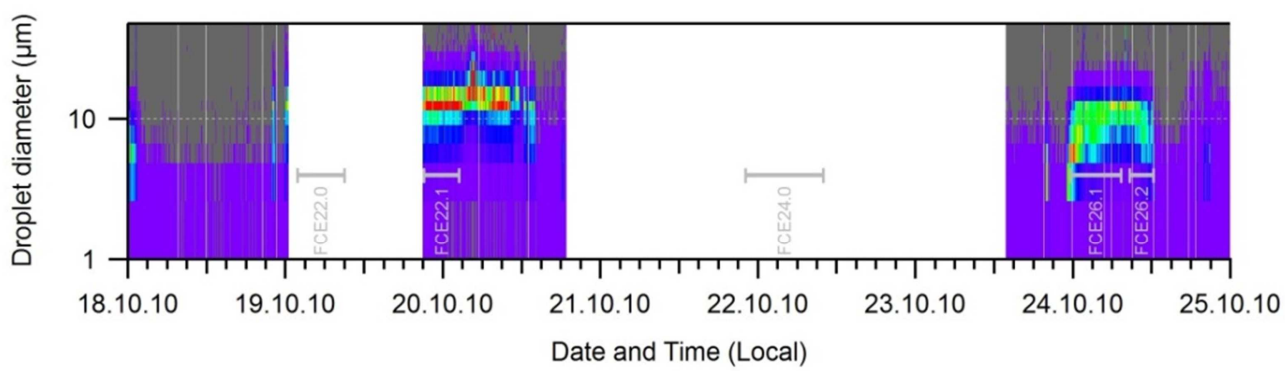

Figure S4: Time series of cloud droplet size distributions measured during HCCT-2010. The full cloud events as defined in Tilgner et al. (2014) are indicated. During FCE22.0 and FCE24.0 the FSSP was not operated due to icing at the instrument tip. 

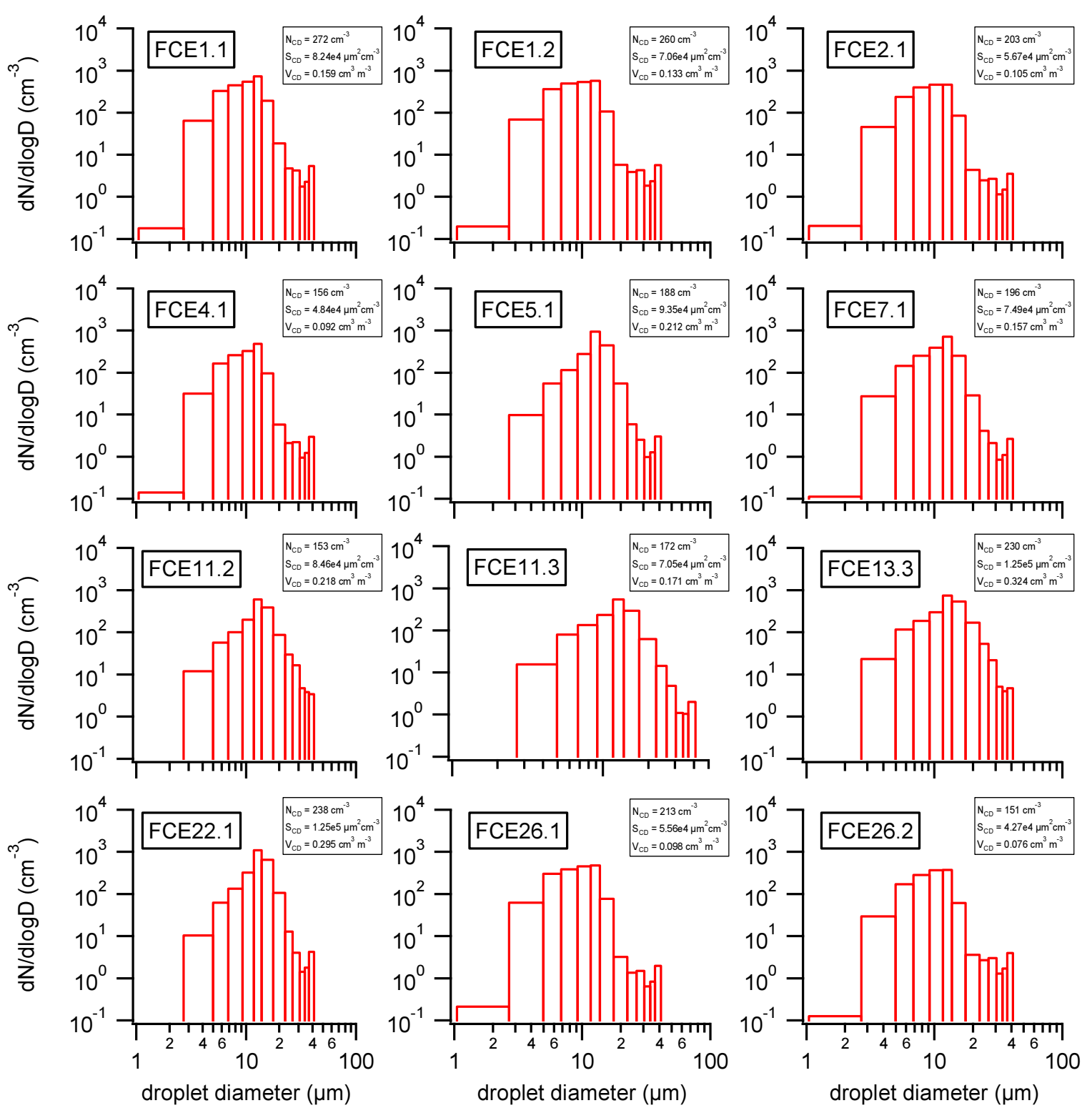

Figure S5: Number size distribution of cloud droplets measured by the FSSP-100 for all full cloud events (FCE) as given in Table 1 of the main text. The averaging times correspond to those given in Table 1, except for FCE1.1, where the first 2 hours and 23 minutes are missing, and 11.3, where the last $4 \mathrm{~h} 21 \mathrm{~m}$ are missing. During FCE22.0 and FCE24.0 the FSSP was not operated due to icing at the instrument tip. Averaged parameters are given in the legend $\left(\mathrm{N}_{\mathrm{CD}}\right.$ : Cloud droplet number concentration, $\mathrm{S}_{\mathrm{CD}}$ : Cloud droplet surface concentration, $\mathrm{V}_{\mathrm{CD}}$ : Cloud droplet volume concentration). 

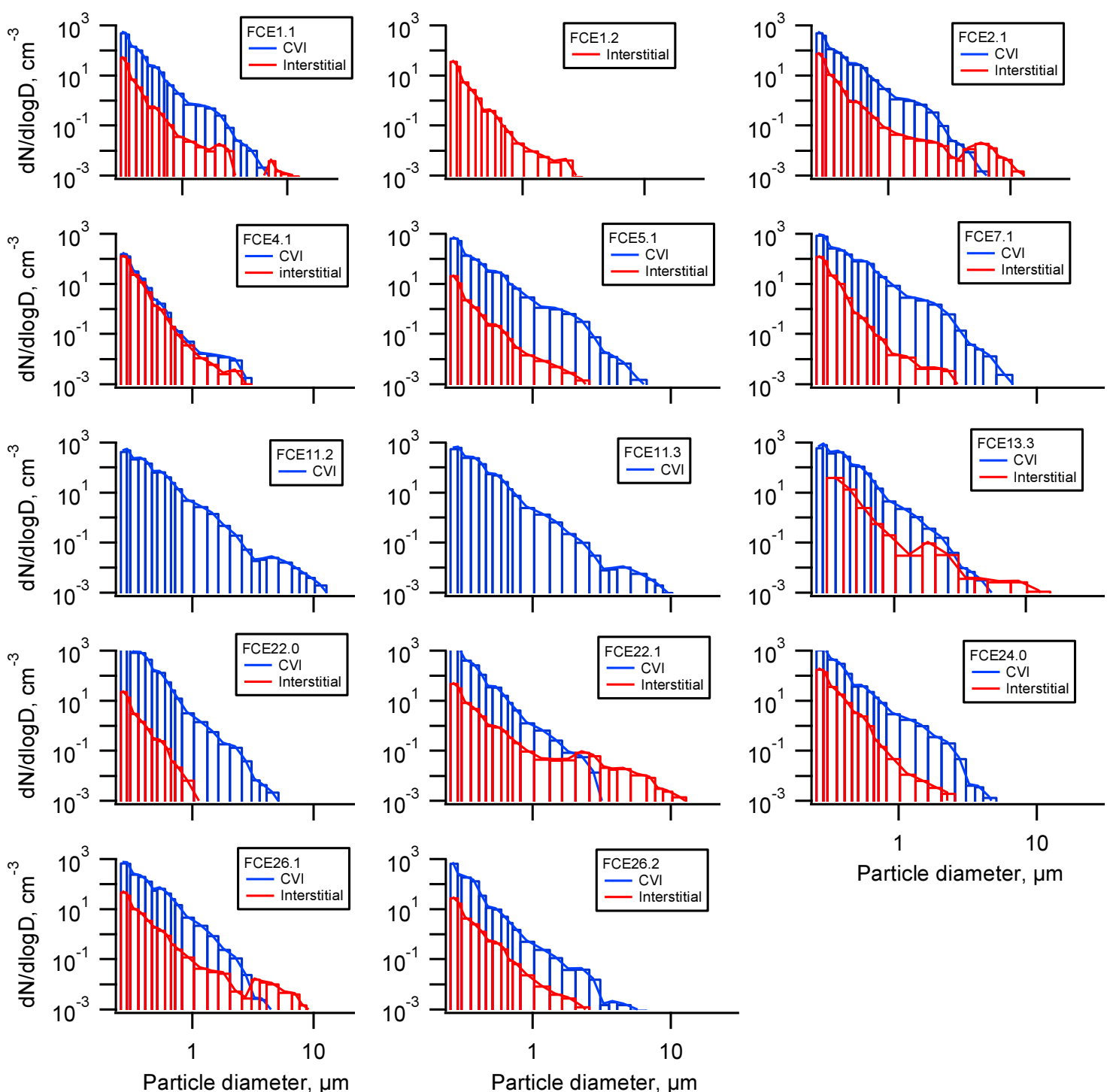

Particle diameter, $\mu \mathrm{m}$

Figure S6: Size distributions for all full cloud events (FCE) measured with the optical particle counters (model Grimm 1.109; only the interstitial data during FCE 13.3 were measured by a Grimm 1.108). Missing data (FCE1.2, FCE11.2 and 11.2) are due to instrumental failures. CVI data were corrected for sampling efficiency and enrichment. 
a)

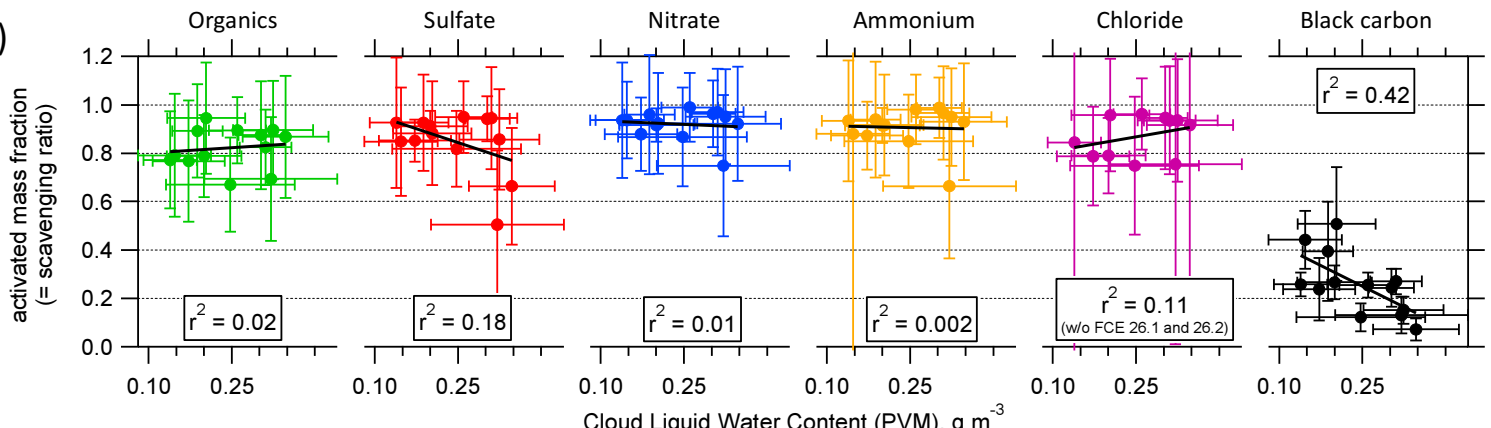

b)

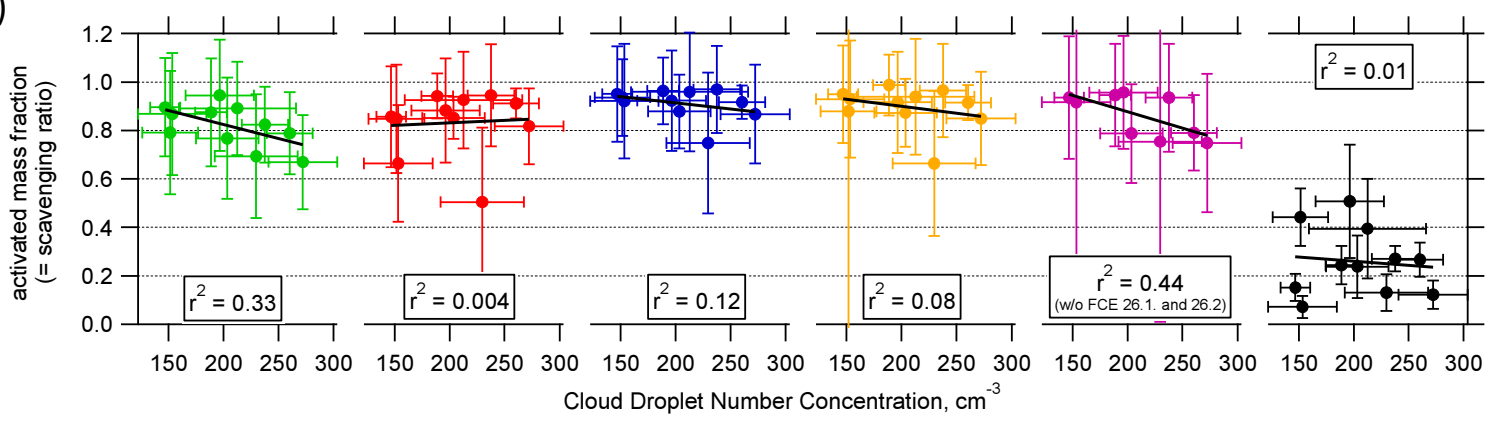

Figure S7: Scavenging efficiency as a function of liquid water content (upper panel) and of cloud droplet number concentration (lower panel). Linear regression lines were fitted to the data and correlation coefficients are given. For FCE 22.0 and 24.0 no FSSP data are available. There is almost no correlation between the scavenging efficiency and LWC. Chloride shows a positive linear correlation with a correlation coefficient $\left(r^{2}\right)$ of 0.11 , whereas sulfate and black carbon show negative correlations with $r^{2}=0.18$ and 0.42 , respectively. It has to be noted the FCE26.1 and FCE26.2 were not used for chloride because the mass concentrations were below the detection limit. Especially the negative correlation of $S E_{\text {sulfate }}$ with $\mathrm{LWC}$ is in contradiction to observations by Kasper-Giebl et al. (2000) who found a constant increase of $S E_{\text {sulfate }}$ with LWC. Also the SE values show no clear correlation with CDNC (lower panel), in four cases negative correlations are found: Chloride $\left(r^{2}=0.44\right)$, organics $\left(r^{2}=0.33\right)$, nitrate $\left(r^{2}=0.12\right)$, and ammonium $\left(r^{2}=0.08\right)$. An explanation might be that the variation from one cloud event to the other is too high to observe the effects of uptake from the gas-phase and in-cloud production. 

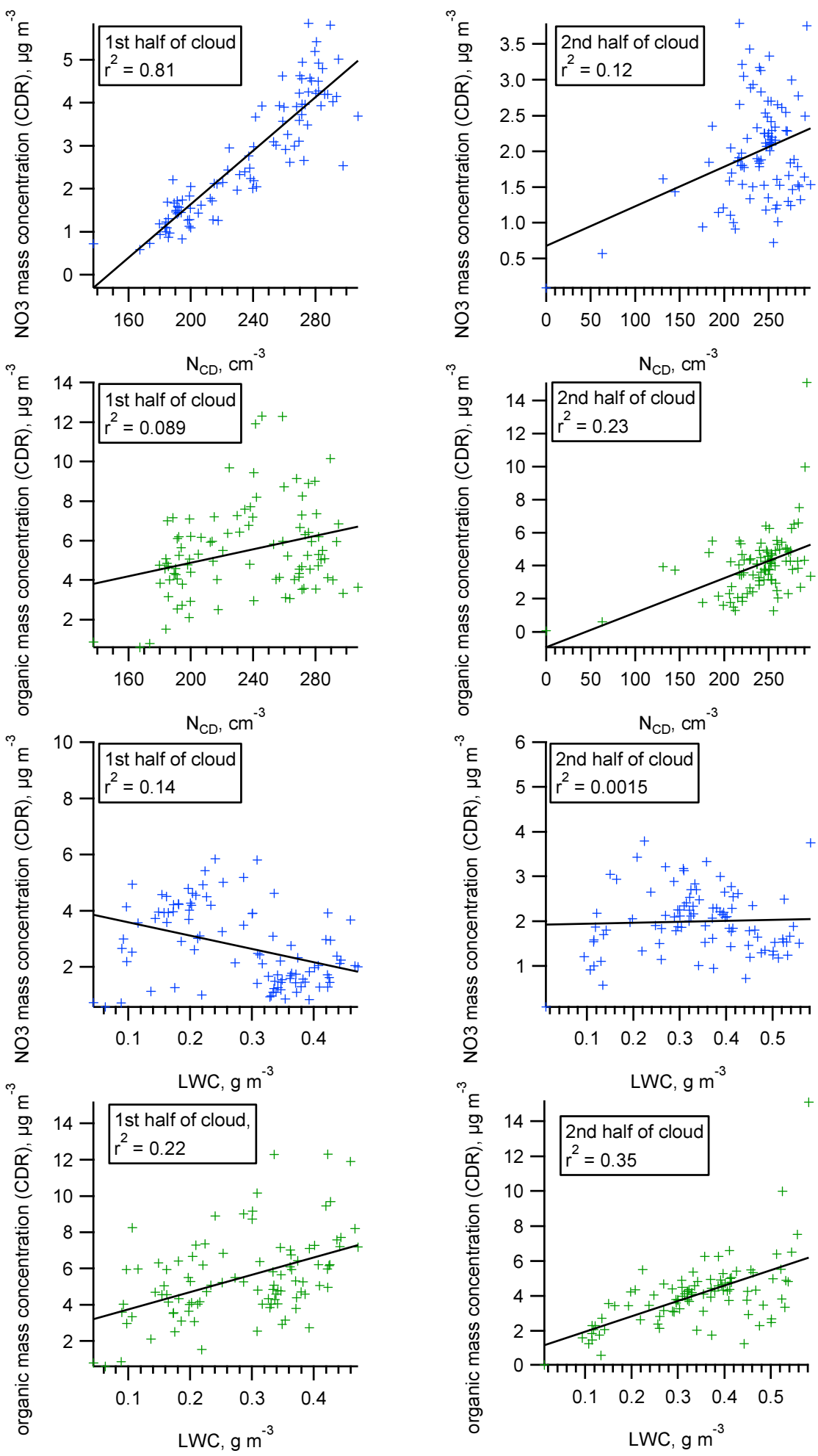

Figure S8: Mass concentrations of nitrate and organics in CDR vs CDNC and LWC during the cloud on $05-07$ October 2010. Correlations were calculated separately for the first and second half of the cloud (first half: 05.10.2010 19:45 - 06.10.2010 11:55; second half: 06.10.2010 12:05 - 07.10.2010 03:35) 


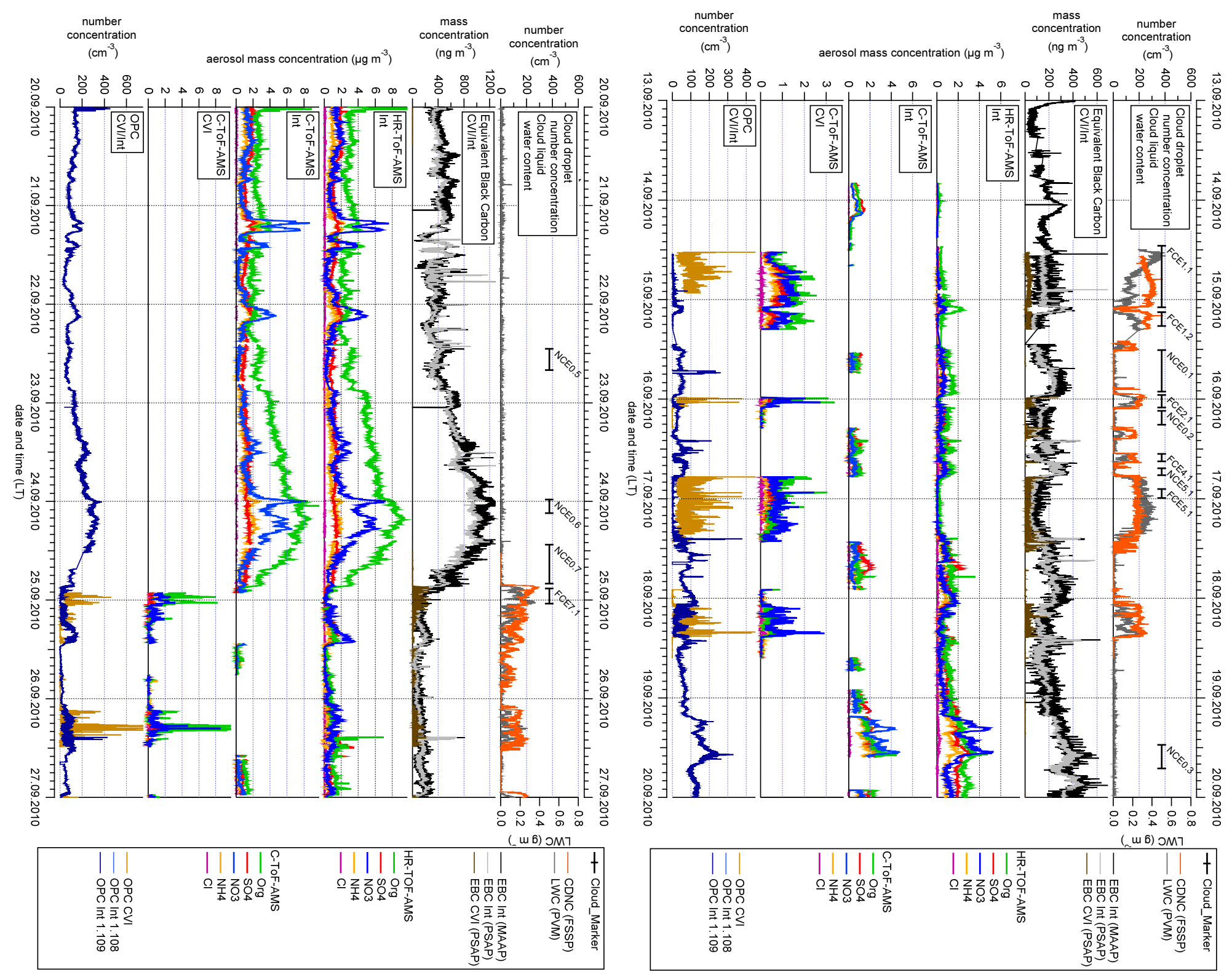




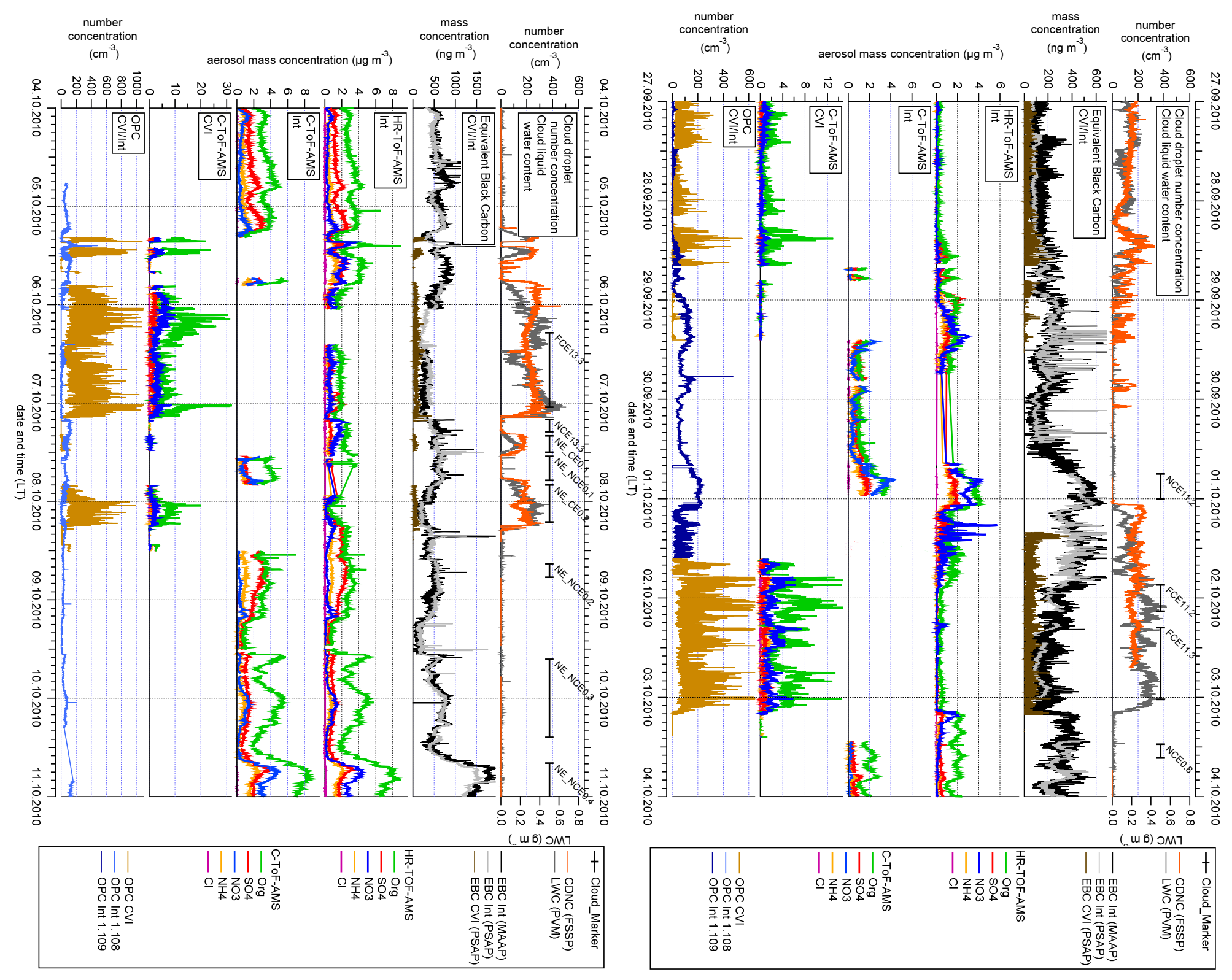



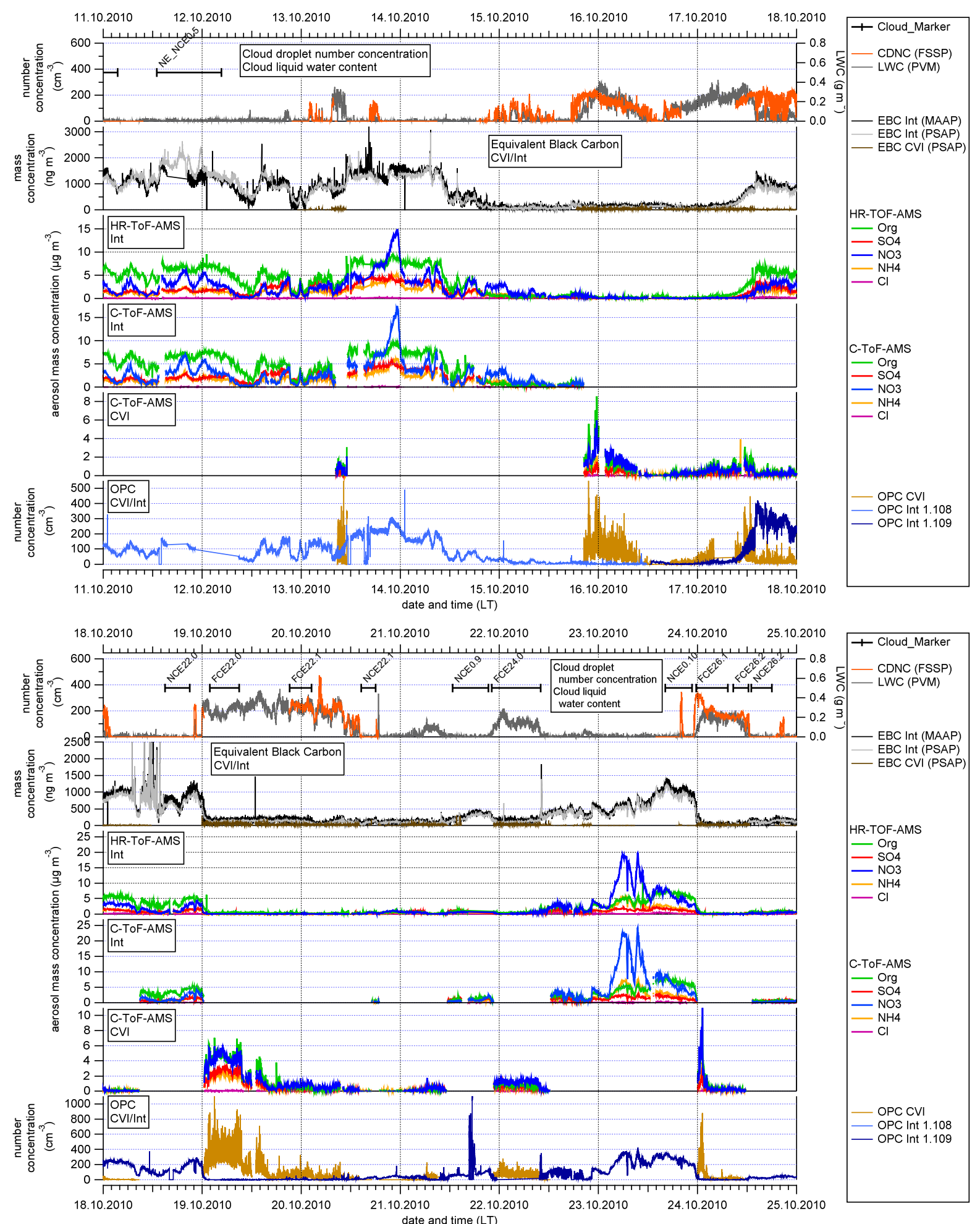

Figure S9: Times series of the measured parameters. In the upper panel the cloud events (FCE), non-cloud events ("NCE") and other reference periods as defined in Tilgner et al. (2014) are given. "Int" denotes the interstitial inlet. 


\section{References}

Alfarra, M. R., Coe, H., Allan, J. D., Bower, K. N., Boudries, H., Canagaratna, M. R., Jimenez, J. L., Jayne, J. T., Garforth, A. A., Li, S. M., and Worsnop, D. R.: Characterization of urban and rural organic particulate in the lower Fraser valley using two aerodyne aerosol mass spectrometers, Atmos. Environ., $38,5745-5758,2004$

Canagaratna, M. R., Jayne, J. T., Jimenez, J. L., Allan, J. D., Alfarra, M. R., Zhang, Q., Onasch, T. B., Drewnick, F., Coe, H., Middlebrook, A., Delia, A., Williams, L. R., Trimborn, A. M., Northway, M. J., DeCarlo, P. F., Kolb, C. E., Davidovits, P., and Worsnop, D. R.: Chemical and microphysical characterization of ambient aerosols with the aerodyne aerosol mass spectrometer, Mass Spectrom. Rev., 26, 185-222, 2007.

Kasper-Giebl, A., Koch, A., Hitzenberger, R., and Puxbaum, H.: Scavenging Efficiency of 'Aerosol Carbon' and Sulfate in Supercooled Clouds at Mt. Sonnblick (3106 m a.s.1., Austria), J. Atmos. Chem., 35, 33-46, doi: 10.1023/A:1006250508562, 2000.

Takegawa, N., Miyazaki, Y., Kondo, Y., Komazaki, Y., Miyakawa, T., Jimenez, J. L., Jayne, J. T., Worsnop, D. R., Allan, J. D., and Weber, R. J.: Characterization of an Aerodyne Aerosol Mass Spectrometer (AMS): Intercomparison with other aerosol instruments, Aerosol Sci. Technol., 39, 760-770, 2005.

Tilgner, A., Schöne, L., Bräuer, P., van Pinxteren, D., Hoffmann, E., Spindler, G., Styler, S. A., Mertes, S., Birmili, W., Otto, R., Merkel, M., Weinhold, K., Wiedensohler, A., Deneke, H., Schrödner, R., Wolke, R., Schneider, J., Haunold, W., Engel, A., Wéber, A., and Herrmann, H.: Comprehensive assessment of meteorological conditions and airflow connectivity during HCCT-2010, Atmos. Chem. Phys., 14, 91059128, doi: 10.5194/acp-14-9105-2014, 2014. 